\title{
The Values of Character in Traditional Games Simalungun Society
}

\author{
Ramlan Damanik ${ }^{1}$, Warisman Sinaga ${ }^{2}$ \\ ${ }^{1,2}$ Faculty of Humanities, Univesitas Sumatera Utara, Indonesia \\ ramlan1@usu.ac.id
}

\begin{abstract}
Simalungun ethnic is one of the ethnic in North Sumatra, Simalungun ethnic have some traditional games, marlubuk,marsitengka, marjalengkat, batu marsiada (mardara), marultop, margala, margodok, pattik lele, pecah piring, olei,olei, margasing, jalengkat sarip, marjakop, dan marampera. Discussions with an informan and immediately held a game involve some children in Sirpang Sigodang Kecamatan Raya village, for get Simalungun traditional games' type. Methods such as recording, documenting, interviewing have eighteen character values, among others: religious values, honesty, tolerance, discipline, hard work, creative thinking, independence / independence, democracy, curiosity, national spirit, patriotism, appreciation for achievement, hospitality, peace, love to read, protect the environment, social care, and responsibility. Simalungun traditional games can be played at school, some friends in neighborhood for form character values.
\end{abstract}

Keywords traditional games, character values, Simalungun

\section{Introduction}

Long before children know gadget, they used they free time with playing traditional games. The games that they did is a heriditary from the old generation. Playing is a nature behaviour of a child, playing have important meaning in their life. Traditional games for the child can express themselves so they can make any creativities and skills that can support them to be a child of positive character. Lucia (2011) said that traditional games encourage creative activities includ imaginative and self-expression. Misbach, (2006) said that traditional games are activities spontaneously, without burden and without binding rules. When playing the traditional games, the child explores and finds out for themselves the very thing to make they proud and happy. Through traditional games that are played by the children will form positive characters that are very useful for life later.

Simalungun as one of etnic in Indonesia especially North Sumatera has traditional games. The traditional games of etnic simalungun which is the part of simalungun culture, it was the result of the cultural heritage from the ancestors that should we keep because it has elements that can be our guidelines from clever intelligence, physical dexterity, and proficiency in doing something in a game. The orogin of this traditional games is not known.

So that, it can not deny that the simalungun traditonal games need to be brought its function as a development character given and identity of Indonesia people in general and simalungun generation especially who are superior and responsive of the demands of this era without being revoked from the identity of cultural roots. Although traditional games has seldom to be found, but there are still some Indonesia children in remote area that play this traditonal games. Even in big cities like Surabaya, Nusat Tenggara Barat still could be found some children who play the traditional games, even the simalungun traditional 
games like marjalengkat, marsitengka, margalah often to be competed in some evens like toba lake festival, rondang bintang even, and Pematang Siantar anniversary. The traditioonal games is often used by pshycolog as a way to develop children intelligence.

\section{Review of Literatures}

\subsection{The Characteristic Theory}

So many defenition of character was disclosed by science, in language, chacarter is taken from Greek that has meaning "to mark" and to focus, to applied the value of kindness in the form of action and attitude literally. Based on the National Education Center, the character is "innate, heart, soul, personality, character, behavior, personality, character, character, temperament, character ". Lickona (1992: 51) said: Character consist of operative values, values in action. Character conceived has three interrelated parts: moral knowing, moral feeling and moral behavior. Good character consists of knowing the good, desiring the good and doing the good-habits of the mind, habits of the heart and habits of action.

Tadkroatun (2008) explain that character is an attitudes, behaviors, motivations, and skills. Therefore it can be conclude that character is the value of behavior of human activities which related to themselves, others, their environment, and with their God, manifested in values, attitudes, actions, motivations, religion, legal and cultural norms. The value of the characteristic in traditional games are 18 characters (Sibarani 2012: 142, 2015:62) the 18 characters include 1) religiousvalues;2) honest; 3) tolerance; 4) dicipline; 5) hard work; 6) creative idea; 7) independent; 8) democtratic; 9) curious; 10) spirit of nationality; (11) patriotism; (12) appreciation for achievement; (13) friendly; (14) peaceloving; (15) likes to read; (16) to guard environment; (17) social care; and (18) responsibility.

\subsection{Traditional Games}

James Dananjaya (1987:35) give his opinion that traditional games is a game which is known by oral among the collective members in traditional and inherited from generation to generation and have some variation. At this time, traditional games have so many variation. The nature of this traditional games is very old, unknown about the origin and the creator, and where it come from. The nature and characteristic of this traditional games are spread orally by mouth to mouth and sometimes changing the form and the name altough it has the same basic. Looking at the root of the words traditional games is the activity that is arranged by one of the game which is heritage from the old generation with the purpose getting happiness. Traditional games need good skill from the players, the charatectersitic of this game not only entertaint the audience but also the players. Beside of needing a good skill, traditional games also contains the value of characteristic.

Traditional games come from the cultural environment of a society. Games and toys are very closely related to a child psychology and positively affect the child's cognitive development. Traditional games usually played by children and adults in reflecting harmonious relationships with the nature while at the same time increases children's creativity, for example learning how to make tools used during play that are made from materials naturally available in their surroundings (Lewier, 2020). 


\section{Research Methods}

This research used descriptive method with aproach qualitative, that describe about the object that should be research and then describe systematic with the founded data in the area (Moelong 2007:16).

\section{Results and Discussion}

Depends on the data which is get from observation and interview from subject of research and informant has found the values of character in simalungun traditonal games. As for the type and character of simalungun traditonal games, depends on science among others:

Table 1. The values of character in simalungun traditonal games

\begin{tabular}{|c|c|c|c|}
\hline No & Name of Games & Values of Character & Information \\
\hline 1 & $\begin{array}{l}\text { Marlubuk is a games that } \\
\text { has } 16 \text { holes, } 2 \text { are main } \\
\text { of holes and } 14 \text { holes } \\
\text { which is filled with } 7 \\
\text { seeds. Two players will } \\
\text { play together to fill the } \\
\text { small hole and the main } \\
\text { hole. If one of them run } \\
\text { out the seeds in the small } \\
\text { hole, so that can be shot } \\
\text { the seeds in the } \\
\text { opponent's area }\end{array}$ & Honest, dicipline, creative assesment. & $\begin{array}{l}\text { Played by two } \\
\text { players. }\end{array}$ \\
\hline 2 & $\begin{array}{l}\text { Marjalengkat this game } \\
\text { is stand on } 2 \text { bamboos } \\
\text { with the length } 2-3 \\
\text { mteres and given the bar } \\
\text { as a foothold, players } \\
\text { will race by using the } \\
\text { two bamboos to reach the } \\
\text { finish line, the present of } \\
\text { the winner is the will } \\
\text { carried along the field }\end{array}$ & $\begin{array}{l}\text { Honest, dicipline,hard work, creative } \\
\text { assesment ,independent, awards and } \\
\text { achievements. }\end{array}$ & $\begin{array}{l}\text { Played by two } \\
\text { players is two } \\
\text { people and } \\
\text { sometimes in } \\
\text { group or team }\end{array}$ \\
\hline 3 & $\begin{array}{l}\text { Marsitengka : this game } \\
\text { is in the form of woman } \\
\text { clothes and defided in to } \\
\text { some boxes. The games } \\
\text { begin with marsuten and }\end{array}$ & $\begin{array}{l}\text { Honest, hard work, creative assesment } \\
\text {,democratic, achevements and dicipline. }\end{array}$ & $\begin{array}{l}\text { The minimum } \\
\text { of the player is } \\
\text { two people and } \\
\text { can be played } \\
\text { in group }\end{array}$ \\
\hline
\end{tabular}




\begin{tabular}{|c|c|c|c|}
\hline & $\begin{array}{l}\text { the winner will be the } \\
\text { first player who start the } \\
\text { game by throwing gasok } \\
\text { loppah in to the first box } \\
\text { till the last box named } \\
\text { kotak balon. In a way } \\
\text { the player turn their back } \\
\text { to the game box and } \\
\text { throwing gasok/oppah } \\
\text { into the the game box. If } \\
\text { they succed to throwing } \\
\text { the gasok into the last } \\
\text { box, they will get much } \\
\text { score }\end{array}$ & (a) & \\
\hline 4 & $\begin{array}{l}\text { Marsada stone game / } \\
\text { mardara; played by the } \\
\text { girls by taking stones } \\
\text { from the ground. The } \\
\text { minimum number of } \\
\text { stones is } 10\end{array}$ & Honest, dicipline, hard work & $\begin{array}{l}\text { The minimun } \\
\text { of the players } \\
\text { is two people } \\
\text { and played in } \\
\text { group or team }\end{array}$ \\
\hline 5 & $\begin{array}{l}\text { Margalah : The game } \\
\text { was very populer before } \\
\text { the children know } \\
\text { gadget. The children who } \\
\text { play this game will try to } \\
\text { break the lines which is } \\
\text { guarded by opponents to } \\
\text { reach the finish line } \\
\text { Hard work will show by } \\
\text { the both of the groups, } \\
\text { the play group will try } \\
\text { reach the finish line } \\
\text { withoutbeing touched by } \\
\text { the guard group will try } \\
\text { to touch the players who } \\
\text { play on it, so the } \\
\text { situation turns arround } \\
\text { the players who play on } \\
\text { it, so the situation turns } \\
\text { arround, the play group } \\
\text { will be a play group. }\end{array}$ & $\begin{array}{l}\text { Honest, dicipline , hard work, } \\
\text { democrazy and responsibility . }\end{array}$ & $\begin{array}{l}\text { Must be even a } \\
\text { minimum of } \\
\text { people are } 6\end{array}$ \\
\hline 6 & $\begin{array}{l}\text { Marultop : The game is } \\
\text { like playing a game } \\
\text { between two groups the } \\
\text { weapon made from }\end{array}$ & $\begin{array}{l}\text { Honest, hard work, creative } \\
\text { thinking, national spirit, } \\
\text { patriotism, and love for peace }\end{array}$ & $\begin{array}{l}\text { The game can } \\
\text { be played by } \\
\text { groups and the } \\
\text { minimum of }\end{array}$ \\
\hline
\end{tabular}




\begin{tabular}{|c|c|c|c|}
\hline & $\begin{array}{l}\text { bamboo. Marultop game } \\
\text { played by two groups . } \\
\text { But each group did not } \\
\text { shoot in the eye of } \\
\text { apponent and minimum } \\
\text { shooting distance of } 1 \\
\text { meter from the opposing }\end{array}$ & & $\begin{array}{lll}\text { group is } 4 \\
\text { people }\end{array}$ \\
\hline 7 & $\begin{array}{l}\text { Margodok: Is a game } \\
\text { liked by children at the } \\
\text { time, this game can be } \\
\text { played at any time } \\
\text { because it does not } \\
\text { require tools. A child is } \\
\text { be a ple guard and others } \\
\text { hide, pole guard will try } \\
\text { to find the opponent } \\
\text { woulf say the name een } \\
\text { by the guards while } \\
\text { running toward pole . } \\
\text { And if all can be found, } \\
\text { then the next guard is the } \\
\text { first to found and if not } \\
\text { all can be while there. }\end{array}$ & $\begin{array}{l}\text { Honest, dicipline, democratic, } \\
\text { and responsibility. }\end{array}$ & $\begin{array}{l}\text { The game } \\
\text { played in a } \\
\text { crowd. }\end{array}$ \\
\hline 8 & $\begin{array}{l}\text { Pattik lele: The category } \\
\text { of this hard game, the } \\
\text { tools made by hard } \\
\text { woods, this game is } \\
\text { prediminantly played by } \\
\text { boys. This game consist } \\
\text { of } 2 \text { component, the first } \\
\text { is anak pattik lele which } \\
\text { is a short wooden stick } \\
\text { and long wood is called } \\
\text { the main wood. The main } \\
\text { wood will bring up a } \\
\text { short wood place on the } \\
\text { ground size } 18-20 \mathrm{~cm} \\
\text { and diameter of } 0,75 \mathrm{~cm} \text {. } \\
\text { And if short wood caught } \\
\text { by the guard teamthen } \\
\text { the game will switch to } \\
\text { the main team and } \\
\text { otherwise }\end{array}$ & $\begin{array}{l}\text { Honest, hard work, creative } \\
\text { thinking, curiosity, appreciation, } \\
\text { achievement and discipline , } \\
\text { religious, tolerance. }\end{array}$ & $\begin{array}{l}\text { The game } \\
\text { played by the } \\
\text { groups }\end{array}$ \\
\hline
\end{tabular}




\begin{tabular}{|c|c|c|c|}
\hline 9 & $\begin{array}{l}\text { Pecah piring: This game } \\
\text { played by two teams, } \\
\text { which is one team have } \\
4-5 \text { players, using } 7-10 \\
\text { the pieces of tile that the } \\
\text { top , baseball is used to } \\
\text { throw stones, the first } \\
\text { team served as a play } \\
\text { team and others served as } \\
\text { guard team. If the guard } \\
\text { team succeeds in } \\
\text { throwing the ball and the } \\
\text { playing team then the } \\
\text { game will change, and } \\
\text { the play team will be the } \\
\text { guard team, the guard } \\
\text { team willbe the play } \\
\text { team etc. }\end{array}$ & $\begin{array}{l}\text { Honest , religious, tolerance , } \\
\text { hard work , awards and } \\
\text { achievements, } \\
\text { responsibilities. }\end{array}$ & $\begin{array}{l}\text { This game can } \\
\text { played by the } \\
\text { groups, can be } \\
\text { six to ten } \\
\text { people in one } \\
\text { group }\end{array}$ \\
\hline 10 & $\begin{array}{l}\text { Olei Olei : Before the } \\
\text { gadget is growing rapidl } \\
\text {, this olei olei game is } \\
\text { often found by children } \\
\text { the aged } 5 \text { to } 12 \text { years. In } \\
\text { village this game often } \\
\text { do at night so many } \\
\text { players. Olei olei game } \\
\text { played by } 7-10 \text { childern, } \\
\text { the way to play begins } \\
\text { with the determination of } \\
\text { who will be the guard } \\
\text { the guard consist of } 2 \\
\text { people that has a mission } \\
\text { to catch one of the } \\
\text { players. These two } \\
\text { people will do hompimpa } \\
\text { or lottery for detemine } \\
\text { who will be the player } \\
\text { and who will be the } \\
\text { guard. Face to face with } \\
\text { hands holding the head in } \\
\text { a tunnel , while the } \\
\text { others childern parade } \\
\text { and sing a song }\end{array}$ & $\begin{array}{l}\text { Religious, hard work, } \\
\text { independent and responsible. }\end{array}$ & $\begin{array}{l}\text { This game can } \\
\text { be played by } \\
\text { seven to ten } \\
\text { people in one } \\
\text { group. }\end{array}$ \\
\hline 11 & $\begin{array}{l}\text { Margasing : This game } \\
\text { is a unique game because } \\
\text { must have dexterity and } \\
\text { ability , the tools of } \\
\text { margasing game made } \\
\text { from the hartd wood, }\end{array}$ & $\begin{array}{l}\text { Religious, discipline, creative, } \\
\text { peacefull. }\end{array}$ & $\begin{array}{l}\text { This game } \\
\text { played with } \\
\text { individual or } \\
\text { groups. }\end{array}$ \\
\hline
\end{tabular}




\begin{tabular}{|c|c|c|c|}
\hline & $\begin{array}{l}\text { like mangroove wood } \\
\text { that grows on the beach, } \\
\text { guaya steam, banana tree } \\
\text { trunk, teak tree trunk, } \\
\text { hard wood trunk and pine } \\
\text { logs. And the selection of } \\
\text { raw materials or logs } \\
\text { greatly determine the } \\
\text { toughness and qualityof } \\
\text { the spinner. There are } \\
\text { two kinds of this game, } \\
\text { among others in a way } \\
\text { whose stopped the } \\
\text { spinning longer in the } \\
\text { circle, and the second } \\
\text { race when the spinning is } \\
\text { rotate in the circle and } \\
\text { the enemy will strike the } \\
\text { spinning in the circle. } \\
\text { This second type of race } \\
\text { depends onthe way strike } \\
\text { spinning the spinning of } \\
\text { enemy. }\end{array}$ & 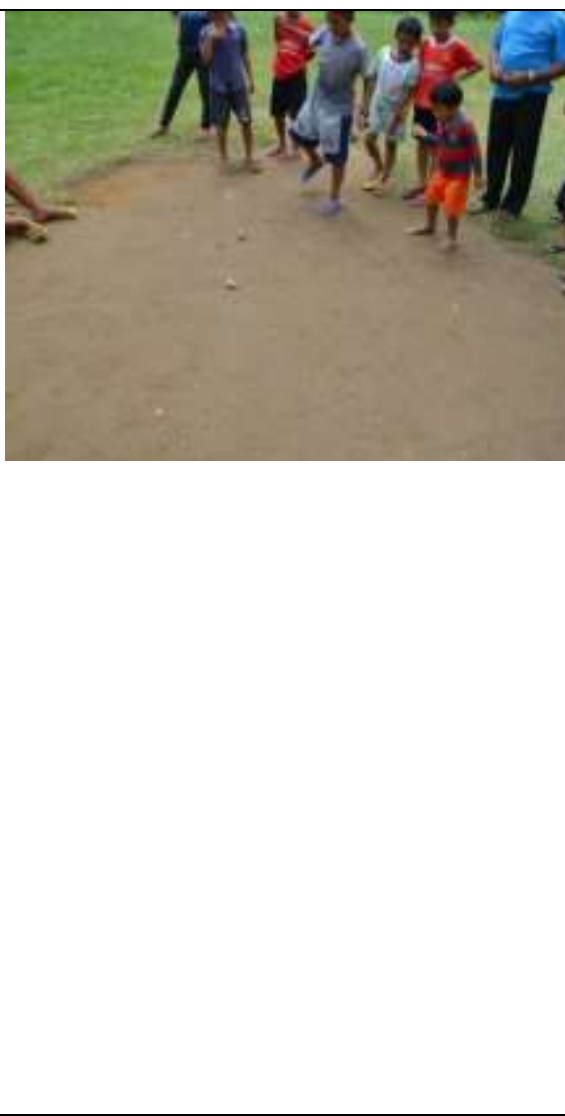 & \\
\hline 12 & $\begin{array}{l}\text { Jalengkat sarip: This } \\
\text { traditional game is } \\
\text { almost the sam with } \\
\text { marjalengkat game, the } \\
\text { difference is only the } \\
\text { tools to play the game, if } \\
\text { on marjalengkat the tools } \\
\text { are two pieces long } \\
\text { bamboos, so at jalengkat } \\
\text { sarip the tools are shells } \\
\text { and a rope,. The rope is } \\
\text { tie a shell which in the } \\
\text { middle of shell is } \\
\text { perforated so that the } \\
\text { rope binding the shell. } \\
\text { The rules of jalengkat } \\
\text { sarip is same with } \\
\text { marjalengkat games, is a } \\
\text { track and start line and } \\
\text { finish line, and if played } \\
\text { by the team, this game } \\
\text { will played relay, that } \\
\text { each group or team } \\
\text { prepare the players to } \\
\text { play casuaaly or relay }\end{array}$ & $\begin{array}{l}\text { Religious } \\
\text { discipline, hard alue,honest, } \\
\text { creativity,curiosity } \\
\text { responsibility. }\end{array}$ & $\begin{array}{l}\text { This game can } \\
\text { be played by } \\
\text { individuals and } \\
\text { groups. }\end{array}$ \\
\hline
\end{tabular}




\begin{tabular}{|c|c|c|c|}
\hline 13 & $\begin{array}{l}\text { Marjakop; This game is } \\
\text { very exciting game and } \\
\text { full off entertainment and } \\
\text { laughter. This game } \\
\text { played by boys and girls } \\
\text { aged } 8-12 \text { years. This } \\
\text { game can be played up to } \\
30 \text { children. The task of a } \\
\text { children is from the } \\
\text { group. Then two players } \\
\text { will marsuten (suit) to } \\
\text { determine who is the } \\
\text { winner, so that the eyes } \\
\text { of the player is closed by } \\
\text { handkerchief, then the } \\
\text { played who lose when } \\
\text { marsuten will try to catch } \\
\text { the child who wins the } \\
\text { marsuten in the circle } \\
\text { which is made by the } \\
\text { other participants. The } \\
\text { chasing child will say } \\
\text { jakop and the chased } \\
\text { child will say andondo } \\
\text { 'here'. If the chased child } \\
\text { was caught, so the player } \\
\text { change the position being } \\
\text { chased into a chasing } \\
\text { played and they should } \\
\text { becomes the chased } \\
\text { player both of them still } \\
\text { use handkerchief to close } \\
\text { their eyes. }\end{array}$ & $\begin{array}{l}\text { Religious, honest, hard work, } \\
\text { democratic, and responsibility. }\end{array}$ & $\begin{array}{l}\text { This game } \\
\text { can be } \\
\text { played by } 20 \\
\text { up to } \\
30 \text { people }\end{array}$ \\
\hline 14 & $\begin{array}{l}\text { Marampera: This game } \\
\text { is famous in } 70-80 \text { 's, this } \\
\text { game played during } \\
\text { break time. And if at } \\
\text { home, the game played in } \\
\text { evening before evening } \\
\text { bath. Marampera is } \\
\text { played by boys and girls, } \\
\text { the } \\
\text { minimum people of this } \\
\text { game is } 3 \text { people. If } \\
\text { played by } 3 \text { people, so } \\
\text { two people will hold the } \\
\text { rubber between one end } \\
\text { and the other end. Can be } \\
\text { played by the group or }\end{array}$ & $\begin{array}{l}\text { Religious, honest, hard work, } \\
\text { democratic, and responsibility. }\end{array}$ & $\begin{array}{l}\text { Played at least } \\
3 \\
\text { people or a } \\
\text { team }\end{array}$ \\
\hline
\end{tabular}




\begin{tabular}{|l|l|l|}
\hline team. One team or group \\
can be 2-3 peope \\
depends on the deals \\
with the players. This \\
game needs a rubber that \\
is made into one another, \\
and forming flexible rope \\
and long rope. The length \\
is about $3-4$ m, so that it \\
needs so many rubbers.
\end{tabular} \mid \begin{tabular}{|} 
\\
\hline
\end{tabular}

Tabel 2. Recapitulation of character values in traditional games

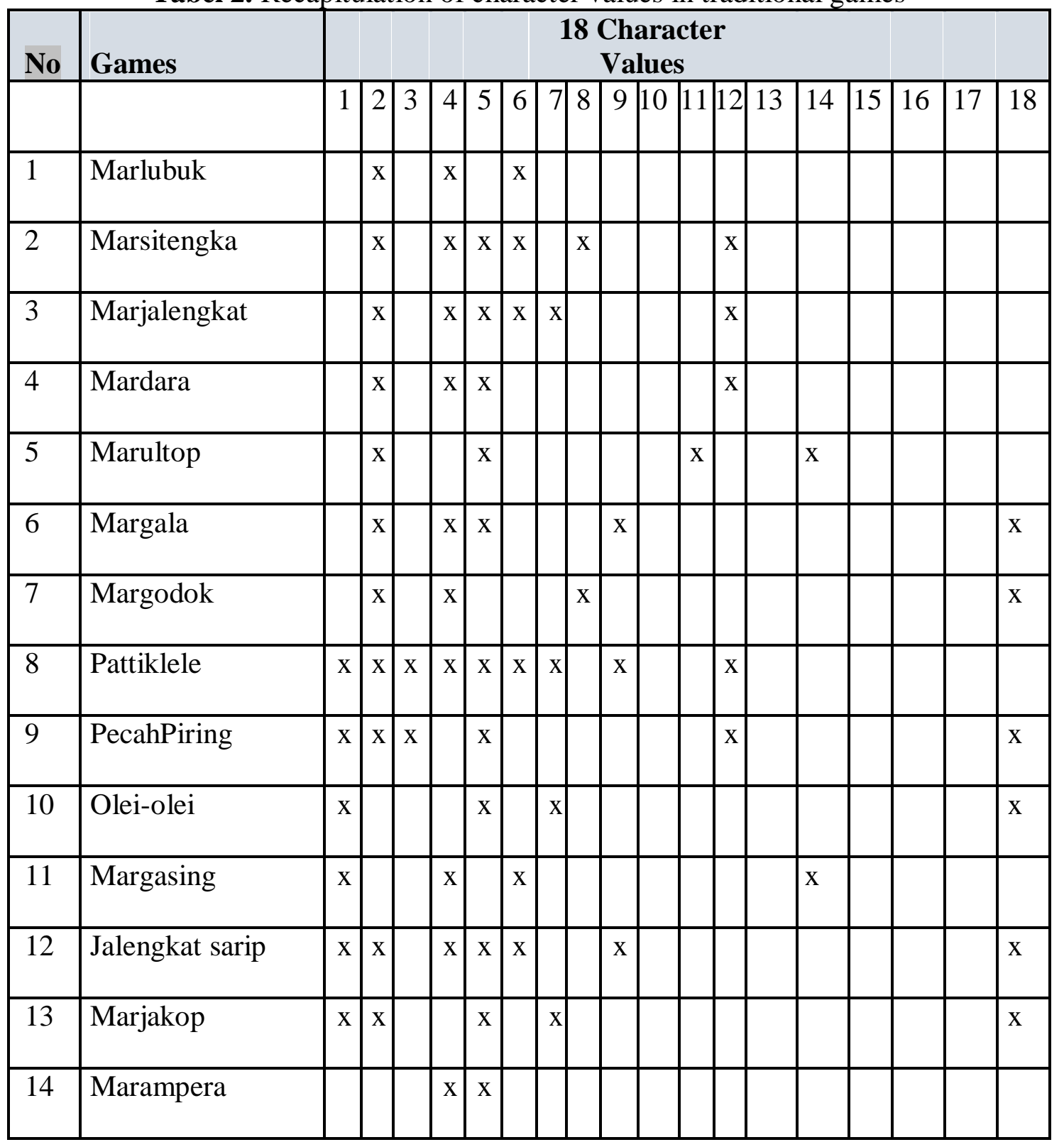


Tabel 3. Recapitulation of the number of players in traditional games

\begin{tabular}{|c|c|c|c|c|c|c|c|}
\hline \multirow[t]{2}{*}{ No } & \multirow[t]{2}{*}{ Games } & \multicolumn{6}{|c|}{$\begin{array}{l}\text { The Number Of Players In } \\
\text { The } \\
\text { Traditional Game } \\
\text { Simalungun }\end{array}$} \\
\hline & & 1 & 2 & 3 & 4 & 5 & $>6$ \\
\hline 1 & Marlubuk & & $\mathrm{x}$ & & & & \\
\hline 2 & Marsitengka & & $\mathrm{X}$ & & $\mathrm{x}$ & $\mathrm{X}$ & $\mathrm{X}$ \\
\hline 3 & Marjalengkat & & $\mathrm{X}$ & & $\mathrm{x}$ & $\mathrm{X}$ & $\bar{x}$ \\
\hline 4 & Mardara & & $\mathrm{X}$ & & $\mathrm{x}$ & & $\mathrm{X}$ \\
\hline 5 & Marultop & & $\mathrm{X}$ & & & & $\mathrm{X}$ \\
\hline 6 & Margala & & & & $\mathrm{X}$ & $\mathrm{X}$ & \\
\hline 7 & Margodok & & $\mathrm{X}$ & & & & $\mathrm{X}$ \\
\hline 8 & Pattiklele & & $\mathrm{x}$ & & $\mathrm{x}$ & & $\mathrm{x}$ \\
\hline 9 & PecahPiring & & & & & & $\mathrm{x}$ \\
\hline 10 & Olei-olei & & & & & & $\mathrm{x}$ \\
\hline 11 & Margasing & & $\mathrm{x}$ & & $\mathrm{x}$ & & $\mathrm{x}$ \\
\hline 12 & Jalengkat sarip & & $\bar{x}$ & & $\bar{x}$ & $\mathrm{x}$ & $\mathrm{x}$ \\
\hline 13 & Marjakop & & & & & & $\mathrm{x}$ \\
\hline 14 & Marampera & & $\mathrm{X}$ & & $\mathrm{x}$ & $\mathrm{X}$ & $\mathrm{X}$ \\
\hline
\end{tabular}

\section{Conclusion}

Traditional games is an acivity which make the players be happy. There are 14 simalungun traditional games which can be described. The 14 traditional games among others: 1. Marlubuk 2. Marsitengka 3. Marjalengkat, 4. Batu Marsiada / Mardara, 5. Marultop, 6, Margala, 7, Margodok, 8. Pattik lele,9. Pecah piring, 10. Olei olei, 11. Margasing, 12. Jalengkat Sarip, 13. Marjakop, 14 Marampera.

Traditonal games can be used to practice and to put the value of character such as religious, honest, tolerance, dicipline, hard work, creative assessment, independent, democratic, curious, spirit of nationality, patriotism, appreciation for achievement, friendly, peace-loving, likes to read, to guard environment, social care and responsibility. For example, in marlubuk we can find the value of character such as: honest, creative assessment, and dicipline. 


\section{Suggestion}

Character building can be done through traditional games, so that to keep it among children, we need to preserve by entering to curiculum so that children can understand how important that traditional games. Considering the value of character in traditional games, it should be improve by the children activity. One of them is to set up a traditional game workshop, in this place the children can be free to play the traditional games. The city government or district government need to revitalize the traditional games in a way to hold a festival contest of traditional games, once in six The city government or district government should provide teaching materials and traditional games guidelines to the teacher. And also, the school prefer to have a big field as a support for the activities of traditional games.

\section{References}

Ekawati, Y. N., Saputra, N. E., Rozalina., Restya, W. P. D., Nurlita, I., (2010). Pengaruh bermain melalui permainan tradisional terhadap kecerdasan intrapersonal anak. Jurnal Ilmiah Mhasiswa berprestasi Vol. 1 No. 2. Universitas Ahmad Dahlan

Internet World Stats Usage and Population Statistics. (2017). Alphabetical List of Countries. Diakses dari http://www.internetworldstats.com pada tanggal 19 Februari 2017.

Lewier, M., et al. (2020). Directive Speech Act in Moluccan Children Traditional Game Songs in Maluku. Budapest International Research and Critics Institute-Journal (BIRCI-Journal). P. 1013-1022.

Lickona, T. (1992). Educating for character, how our schools can teach respect. respect and responsibility. New York: Bantam Books.

Misbach, I. H. (2006). Peran Permainan Tradisional yang Bermuatan Edukatif dalam Menyumbang Pembentukan Karakter dan Identitas Bangsa. Diakses 25 Juni 2016 darihttp://file. upi. edu/direktori/fip/jur. _psikologi/197507292005012ifa_hanifah_misbach/laporan_penelitian_peran_permai nan_tradisional_revisi_final_.Pdf

Moleong, L. J. (2000). Metodologi penelitian kualitatif. Bandung: Remaja Rosdakarya

Nur, H. (2013). Membangun karakter anak melalui permainan tradisional. Jurnal Pendidikan Karakter No. 1. Universitas Negeri Makasar

Pengembangan Pendidikan Budaya dan Karakter Bangsa: Pedoman Sekolah, Badan Penelitian \& Pengembangan-Pusat Kurikulum, Kemdiknas, 2010:3

Sibarani, Robert, 2015. Pembentukan Karakter, Langkah-Langkah Berbasis Kearifan Lokal. Jakarta. Asosiasi Tradisi Lisan (ATL).

Tadkiratun Musfiroh. (2008). Character building. Yogyakarta: Tiara Wacana.

Tedjasaputra, M. (2001). Bermain, Mainan, dan Permainan. Jakarta: Penerbit Grasindo

Yudiwinata, H. P., Handoyo, P, (2014). Permainan tradisional dalam budaya dan perkembangan anak. Jurnal Paradigma Vol. 02 Nomor 3. Universitas Negeri Surabaya. 